\title{
Testicular Cancer cM1 TNM Finding v7
}

National Cancer Institute

\section{Source}

National Cancer Institute. Testicular Cancer CM1 TNM Finding v7. NCI Thesaurus. Code C89266.

Testicular cancer with distant metastasis. (from AJCC 7th Ed.) 